\title{
System dynamics simulation on municipal solid waste in Hong Kong
}

\author{
Chen Wang MIEEE, MRICS, MCRIOCM, MIETI \\ Professor, College of Civil Engineering, Huaqiao University, Xiamen, China \\ (derekisleon@gmail.com)
}

The municipal solid waste (MSW) generation in Hong Kong (HK) is increasing at a rapid pace, resulting in health and environmental issues for the public. Compared with Singapore and Shanghai, HK has a higher MSW generation rate due to less effective measures and government policies. To forecast the MSW generation and recycling in HK, system dynamics modelling was conducted using Vensim 6.0, based on the data collected from semi-structured interviews and official reports in the Environmental Protection Department of HK, the National Environmental Agency Singapore and Shanghai Environmental Protection Agency that regularly provide statistics on waste outputs. The simulation results show that shortly the MSW in HK will increase based on the current growth rates, and along with that, recycling will also increase. The recycling rates will offset that of the MSW generation due to the closure of landfills, and MSW will be effectively recycled due to more advanced disposal techniques. The strategies developed by the HK government will be able to manage the MSW disposal, but the city will experience more severe MSW conditions in the future as its landfills are expected to close earlier than planned. Recommendations for HK to deal with MSW generation were derived from the experiences in Singapore and Shanghai.

\section{Introduction}

Municipal solid wastes (MSWs) are those substances discarded within the municipal area (Wei et al., 2017). The main sources of MSW vary but include commercial, residential, industrial or institutional; each of these can be further segregated into different categories based on the physical composition of wastes (Baawain et al., 2017; Lavee and Khatib, 2010). MSW is a significant issue for Hong Kong (HK) as the MSW amount is increasing at a rapid rate (Ling, 2015). The composition and amount of MSW are determined by factors such as population, income, household size, emigration rate and economic conditions (Cai et al., 2014). The land area in HK is less than 259 square kilometres, but is home to about $7 \cdot 18$ million people. Currently, HK has only three operating landfills and 13 closed landfills (Hong et al., 2010). In 1998, the HK government published a framework on waste reduction to set-out initiatives for the reduction of waste in the city (Chung et al., 2010). After some trials testing the effectiveness of different waste management strategies, a territory-wide programme was developed in 2005 to facilitate the separation of waste in buildings (Chung et al., 2010). The waste disposal ordinance in 1980 provided the statutory framework to manage all types of wastes in HK, which offers licenses for waste collection and disposal facilities (Chan, 2001). The government of HK also developed and enacted the product eco-responsibility legislation in 2008 to manage MSW in the city (Chen et al., 2013). MSW refers to the waste generated by humans in their daily lives (Lee et al., 2016) excluding construction and demolition waste, chemical waste and some special industrial wastes (Prades et al., 2014). The increasing population results in an increase in waste so that the projection of waste generation becomes a critical issue for many cities (Wang et al., 2011). With fast economic development, humans tend to generate more waste, especially when people can spend more and consumption increases (Hong et al., 2017). MSW is piled up and is gradually becoming a major problem due to the complexity in collection and treatment (Lavee and Khatib, 2010). The rapid increase in MSW has stirred up problems such as public health and environmental changes (Antmann et al., 2013).

One of the most common methods used to deal with MSW is landfilling, which has been adopted by many cities around the world leading to the lack of sufficient lands and a strong emergence of landfill gases (Bernstad, 2014). The landfill emissions lead to odour pollution and respiratory diseases (Chowdhury, 2009). HK set the target to raise the MSW recovery from $34 \%$ in 2002 to $36 \%$ in $2004,40 \%$ in 2007 and then $50 \%$ in 2015 . As a comparison, Florida in the USA has decided to increase the MSW recovery rate to $75 \%$ by 2020 (Liyanage et al., 2015). The Environmental Protection Department (EPD) of HK keeps regular statistics on each type of waste. The analysis of these statistics is important as it allows evaluation of whether the system is working properly. System dynamics (SD) is a robust tool that can use these statistics and provide a comprehensive simulation of the waste management process (Kollikkathara et al., 2009). According to Machowski et al. (2008), SD focuses on the feedforward and feedback relationships, and it develops relationships between rate variables and stock variables. SD analyses problems and allows analysis of 
complex, non-linear relationships aided by computer simulations to conceptualise and to rationally analyse structures and interactions and to prognosticate their effects in a holistic way (Inghels and Dullaert, 2010). The HK's daily domestic waste generation rate per capita is much higher than that of other Asian cities such as Shanghai and Singapore. HK is running out of landfilling spaces earlier than planned and the current landfills will be exhausted by 2020 (Liyanage et al., 2015). There is an urgent need to forecast the rapid increasing MSW in HK and to provide accurate modelling for control purposes. In the past, researchers focused on gross domestic product (GDP) as the only indicator of waste generation; however, according to Lam and Chan (2014), other factors such as infant mortality, labour force size, population density and life expectancy should be included. By analysing the historical and current MSW statistics in HK and other Asian cities such as Singapore and Shanghai through interviews and documentation research, this study develops a SD simulation to forecast the future MSW generation in HK for control purposes. A comparison and contrast of MSW analysis between HK, Singapore and Shanghai are provided.

\section{MSW in HK}

The MSW loads in HK were increasing since the year 1986. HK's MSW comprises of over 70\% solid waste, and the daily waste disposal has reached $311 \mathrm{t}$ (Han et al., 2014). Waste recycling is more complex than its reduction. In 1998, the HK government launched the Waste Reduction Framework Plan, which provided a variety of initiatives to reduce waste and recommended a series of measures to promote MSW separation and segregation in HK (Jaillon et al., 2009). The plan was to improve the overall MSW recovery rate from $34 \%$ in 2004 to $40 \%$ in 2007 and to increase the household waste recovery rate from $8 \%$ in 2004 to $20 \%$ in 2007 . The HK government published the first sustainable development strategy in 2005 , including a policy framework for MSW management in HK (Zhang et al., 2012), which proposes a simple and effective tool to create incentives for the community to recycle more and to discard less (Han et al., 2014). For example, the government levies a scheme to direct the economic incentives to reduce the use of plastic shopping bags in the city ( $\mathrm{Lu}$ and Yuan, 2013).

According to Yu et al. (2013), the EPD in HK manages collecting, treating, disposing and transferring MSW in the city; more than $\mathrm{HK} \$ 10$ billion $(\mathrm{HK} \$ 1=£ 0 \cdot 10)$ has been invested in MSW facilities to manage the waste. The waste disposal ordinance was used to control the waste disposal including export and import (Yu et al., 2013). The three operating landfills are located in the new territories, namely: Nim Wang, Tseung Kwan $\mathrm{O}$ and Ta Kwu Ling. Thirteen out of 16 landfills in HK have been closed and restored for several uses to minimise potential health risks. For example, some were landscaped to offer green zones and recreational uses such as golf driving ranges, grass pitches and ecological parks.

There are seven refuse transfer stations located in different areas but with centralised collection points. The waste from smaller refuse collection trucks is compacted and transferred into containers and shipped to landfills through lorries. The chemical waste treatment centre on Tsing Yi Island accepts different chemical and clinical waste. The Sha Ling Composting Plant in the northern new territories accepts livestock waste and composts it into soil suitable for the use in the city. With the efforts of the government and community, the waste recovery rate in $\mathrm{HK}$ has been increasing, and over $80 \%$ of the HK population has been involved in the waste separation programme (Yau, 2010). Materials in MSW such as paints, plastics, disposed goods and inks are considered hazardous (Wei et al., 2017), and the waste management occupies the uppermost rung in the hierarchy of waste management (Zhou et al., 2015). The hierarchy refers to those activities undertaken with an item before it is perceived as waste, which includes the decrease of total waste produced, the decrease in the associated environmental impacts on the public and the decreased quantity of noxious objects (Gidarakos, 2015). Some effective methods for waste reduction include adjustments in the usage of raw materials and the adoption of a suitable production process (Gidarakos, 2015).

\section{MSW in Asian cities}

Asian cities such as HK, Singapore, Shanghai, Taiwan and Beijing are among the leading cities regarding both economic development and waste generation. The city GDP per capita in some Asian megacities such as Bangkok, Shanghai, Jakarta, Manila, Beijing and Kuala Lumpur is two- to five-times higher than other cities. The estimates of expected typical values for MSW in some Asian cities are listed in Table 1. High- and middle-income cities (such as HK, Singapore, Tokyo, Taipei, Seoul, Bangkok, Kuala Lumpur, Beijing and Shanghai) have a

Table 1. Estimated material consumption and waste generating in Asian cities (Ali and Sion, 2014)

\begin{tabular}{|c|c|c|}
\hline Asian cities & $\begin{array}{l}\text { Daily material } \\
\text { consumption: } t\end{array}$ & $\begin{array}{l}\text { Daily municipal } \\
\text { solid waste: } t\end{array}$ \\
\hline $\begin{array}{l}\text { High-income cities: HK, } \\
\text { Singapore, Tokyo, Taipei, } \\
\text { Seoul }\end{array}$ & $6000-14000$ & $500-750$ \\
\hline $\begin{array}{l}\text { Middle-income cities: } \\
\text { Bangkok, Kuala Lumpur, } \\
\text { Beijing, Shanghai }\end{array}$ & $4000-6000$ & $250-550$ \\
\hline $\begin{array}{l}\text { Low-income cities: Manila, } \\
\text { Jakarta }\end{array}$ & $3000-5000$ & $50-250$ \\
\hline $\begin{array}{l}\text { Rural areas in middle-and-low } \\
\text { income regions }\end{array}$ & 500-2000 & 120-200 \\
\hline
\end{tabular}


Table 2. HK compared with some Asian cities (Ali and Sion, 2014)

\begin{tabular}{|c|c|c|c|c|c|c|}
\hline City & $\begin{array}{l}\text { Agriculture area: } \\
\qquad \mathbf{k m}^{2}\end{array}$ & $\begin{array}{l}\text { Forest area: } \\
\qquad \mathbf{k m}^{2}\end{array}$ & $\begin{array}{l}\text { Marine area: } \\
\mathbf{k m}^{2}\end{array}$ & $\begin{array}{l}\text { Total area: } \\
\mathbf{k m}^{\mathbf{2}}\end{array}$ & $\begin{array}{l}\text { Urban density: } \\
\text { people per } \text { km }^{2}\end{array}$ & $\begin{array}{l}\text { MSW per } \mathbf{k m}^{2} \text { city } \\
\text { area: } \mathrm{t} / \mathrm{km}^{2}\end{array}$ \\
\hline $\mathrm{HK}$ & 1800 & 2100 & 20000 & 23900 & 57000 & 1400 \\
\hline Guangzhou & 1000 & 700 & 5000 & 6700 & 2400 & 16 \\
\hline Bangkok & 800 & 300 & 10000 & 11100 & 10000 & 110 \\
\hline Beijing & 600 & 150 & 5000 & 5750 & 20000 & 110 \\
\hline Rural area & 500 & 50 & 2000 & 2550 & n.a. & n.a. \\
\hline Basic cities & 5000 & 1800 & 13300 & 20100 & 10000 & 200 \\
\hline
\end{tabular}

daily material consumption from 4000 to $14000 \mathrm{t}$ and this creates a daily MSW at around 250-750 t. On the other hand, low-income cities such as Manila and Jakarta have a much lower daily material consumption and a MSW generation. The middle- and low-income rural regions have a daily material consumption ranged from 500 to $2000 \mathrm{t}$, and MSW generation from 120 to $200 \mathrm{t}$ (Ali and Sion, 2014). Table 2 shows that HK has higher agriculture, forest, marine and urban density than other cities such as Guangzhou, Bangkok and Beijing.

\section{Research procedures and steps to develop system dynamics model}

SD is a robust process used to analyse complex systems aided by computer simulation. SD can accommodate internal feedback loops and time delays, such as required when forecasting on MSW generation and control. The process of a SD model starts with identifying the parameters; in this study, the parameters refer to those factors for waste generation ( $\mathrm{Liu}$ and $\mathrm{Li}$, 2015). In the past, researchers only focused on GDP as an indicator for waste generation, but Lam and Chan (2014) have suggested that additional factors should be included, particularly (a) population, $(b)$ household size, $(c)$ standard of living and $(d)$ purchasing power. Hong et al. (2010) conceptually describe the relationship between these parameters and MSW generation as higher economic growth leads to higher public spending, which increases the waste generation; higher income leads to higher waste generation; and, more population generates more MSW. HK is a highly populated city with 6650 persons per square kilometre. The median monthly domestic household income is around HK\$22 400, and it is increasing; the total labour force is around 3.86 million people (Cai et al., 2014). In this study, data for SD modelling were collected from semi-structured interviews and official reports in the EPD of HK, Shanghai Environmental Protection Agency and the National Environmental Agency Singapore, which regularly provide statistics on daily/monthly/annual waste outputs in their cities. The Vensim 6.0 software package was used to simulate the dynamic process of the system.

The first step in generating the dynamic simulation was developing the stock-and-flow diagram by defining the variables influencing on MSW generation using the box variable function and rate variable function in Vensim 6.0 as shown in Figure 1. MSW generation is the box variable, and MSW increase rate and MSW decrease rate are the rate variables. The second step was to identify the variables influencing the values. Step 3 is based on the causal loop diagram among variables such as household waste increasing rate, MSW generation per household and household spending per capita rate. The MSW decrease rate was determined in step 4. Step 5 develops causal loop diagram towards the MSW disposal volume, resulting in the decrease in the landfill rate. MSW disposal volume is the starting point followed by MSW recovery rate, total waste disposed and MSW disposal. Step 6 defines the stock-and-flow diagram for landfill in HK, where landfill is a box variable. The simulation as developed at this step could determine the amount of waste disposed at landfills to forecast future waste. Step 7 integrates causal loop diagrams and stock-and-flow diagrams to finalise the SD model.

\section{Finding and results}

\subsection{Limitations of previous research}

Chung (2010) conducted research to forecast MSW in HK until 2036, based on GDP and a linear relationship between GDP growth and MSW increment; a correlation between MSW generation and the population was found to be useful. However, Chung (2010) also identified a key limitation: using GDP for predictions is inaccurate, and it may overestimate the actual quantities of MSW generation. As evidence of this limitation, Table 3 (by Chung, 2010) shows the comparison between the projected quantities based on GDP and the actual quantities of domestic waste disposal.

\subsection{Territorial waste disposal rates and quantity of MSW disposed and recovered}

The GDP per capita (Table 4) and MSW disposal rate and domestic waste disposal rate (Table 5) were collected from the EPD of HK, which regularly monitors MSW in the city. The MSW disposal rate is increasing on a yearly basis. For example, the MSW disposal rate was $1.28 \mathrm{~kg} / \mathrm{d}$ in 1991 but increased to $1.33 \mathrm{~kg} / \mathrm{d}$ in 2013 . On the other hand, the 


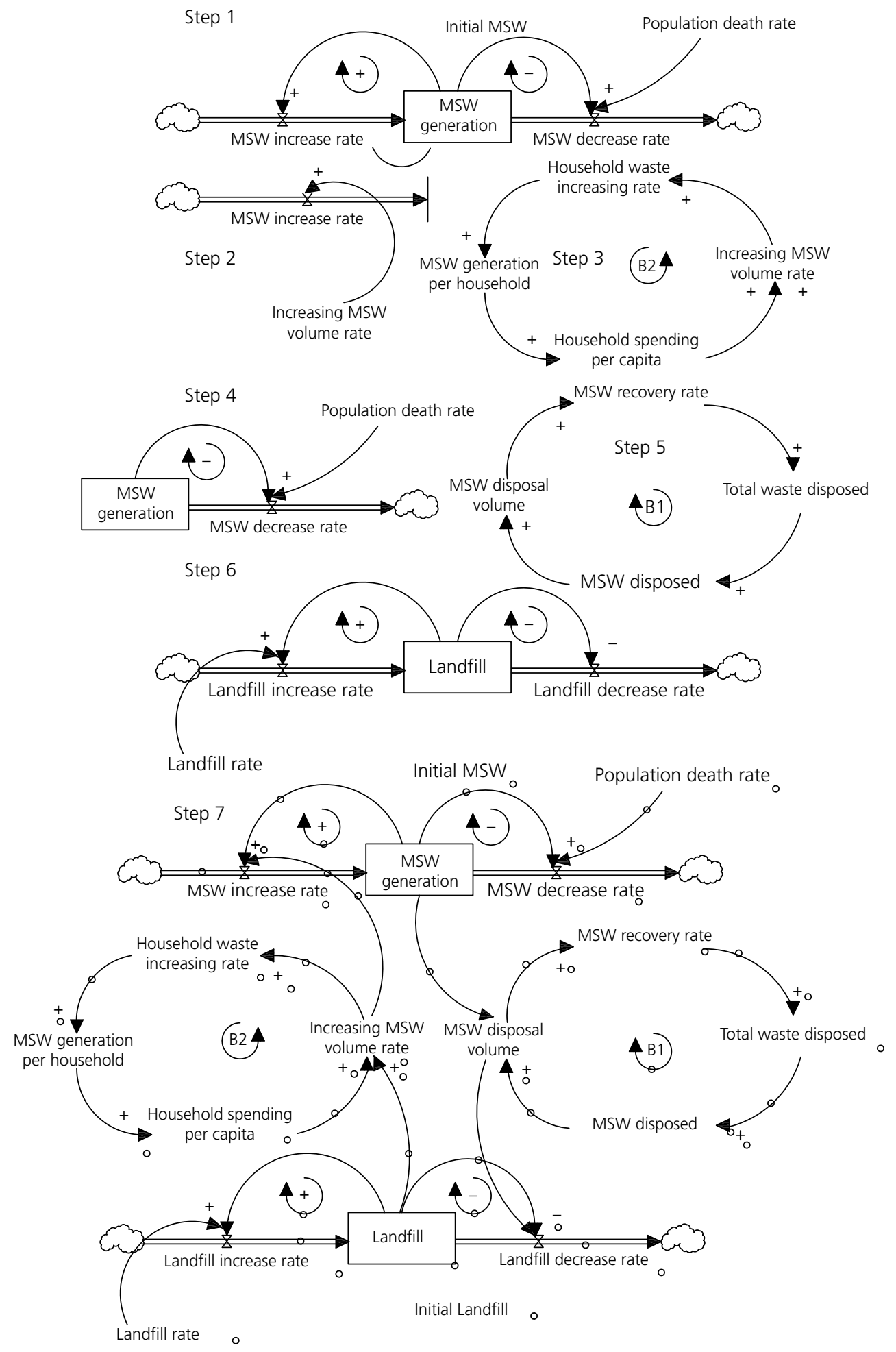

Figure 1. A seven-step SD modelling for MSW forecasting 
Table 3. Waste predictions by Chung (2010)

\begin{tabular}{|c|c|c|}
\hline Forecasts & $\begin{array}{l}\text { Projected } \\
\text { quantities }\end{array}$ & $\begin{array}{c}\text { Actual } \\
\text { quantities }\end{array}$ \\
\hline \multicolumn{3}{|l|}{ Forecasts from 1998 study } \\
\hline MSW in 1996: $t / d$ & 14500 & $8140(+)$ \\
\hline MSW in 2001: t/d & 18600 & $9300(+)$ \\
\hline MSW in 2006: $t / d$ & 23400 & 9279(+) \\
\hline \multicolumn{3}{|l|}{ Forecasts from 1989 to 1900 study } \\
\hline $\begin{array}{l}\text { Per capita domestic waste } \\
\text { disposal rate in } 2001: \mathrm{kg} / \mathrm{d}\end{array}$ & $1 \cdot 3$ & $1 \cdot 12(+)$ \\
\hline $\begin{array}{l}\text { Per capita domestic waste } \\
\text { disposal in 2001: kg/d }\end{array}$ & $1 \cdot 33$ & $1 \cdot 12(+)$ \\
\hline \multicolumn{3}{|c|}{ Forecasts from 1993 to 1994 study } \\
\hline $\begin{array}{l}\text { Per capita domestic waste } \\
\text { disposal in 2006: kg/d }\end{array}$ & $1 \cdot 5$ & $0.97(+)$ \\
\hline \multicolumn{3}{|l|}{ Forecasts from 1995 study } \\
\hline Domestic waste in 2001 & 7830 & $7551(+)$ \\
\hline Domestic waste in 2006 & 9690 & $6634(+)$ \\
\hline \multicolumn{3}{|l|}{ Forecasts from 1996 study } \\
\hline $\begin{array}{l}\text { Per capita domestic waste } \\
\text { disposal in 2001: } \mathrm{kg} / \mathrm{d}\end{array}$ & $1 \cdot 25$ & $0.97(+)$ \\
\hline Forecasts from the 1998 study & 9150 & $6635(+)$ \\
\hline Domestic waste in 2001 & 7460 & $7551(-)$ \\
\hline Domestic waste in 2006 & 8430 & $6634(+)$ \\
\hline \multicolumn{3}{|l|}{ Forecasts from 1998 study } \\
\hline Domestic waste in 2006 & 10090 & $6634(+)$ \\
\hline
\end{tabular}

Table 4. GDP per capita

\begin{tabular}{|cccccc} 
Year & $\begin{array}{c}\text { Housing } \\
\text { estates }\end{array}$ & $\begin{array}{c}\text { GDP per } \\
\text { capita: HK\$ }\end{array}$ & Year & $\begin{array}{c}\text { Housing } \\
\text { estate }\end{array}$ & $\begin{array}{c}\text { GDP per } \\
\text { capita: HK\$ }\end{array}$ \\
\hline 2007 & 700 & 233358 & 2022 & 2015 & 324072 \\
2008 & 865 & 234722 & 2023 & 2015 & 330095 \\
2009 & 1140 & 243227 & 2024 & 2015 & 336298 \\
2010 & 1360 & 252027 & 2025 & 2015 & 342698 \\
2011 & 1574 & 261177 & 2026 & 2015 & 349308 \\
2012 & 1795 & 270679 & 2027 & 2015 & 356144 \\
2013 & 2015 & 275640 & 2028 & 2015 & 363216 \\
2014 & 2015 & 280734 & 2029 & 2015 & 370534 \\
2015 & 2015 & 285957 & 2030 & 2015 & 378117 \\
2016 & 2015 & 291311 & 2031 & 2015 & 385975 \\
2017 & 2015 & 296413 & 2032 & 2015 & 394122 \\
2018 & 2015 & 301652 & 2033 & 2015 & 402563 \\
2019 & 2015 & 307029 & 2034 & 2015 & 411313 \\
2020 & 2015 & 312549 & 2035 & 2015 & 420381 \\
2021 & 2015 & 318229 & 2036 & 2015 & 429774 \\
\hline
\end{tabular}

domestic waste disposal rate has declined, for instance, it was $0.97 \mathrm{~kg} / \mathrm{d}$ in 1991 but only $0.88 \mathrm{~kg} / \mathrm{d}$ in 2013 .

Table 6 lists the MSW disposed and recovered during the year 1991-2013 collected from the EPD of HK, which shows that the amount of MSW disposed and recovered has constantly been increasing from the year 1991 to 2013.
Table 5. MSW disposal rate and domestic waste disposal rate

\begin{tabular}{|c|c|c|}
\hline Year & $\begin{array}{l}\text { MSW disposal } \\
\text { rate: } \mathrm{kg} / \mathrm{d}\end{array}$ & $\begin{array}{c}\text { Domestic waste disposal } \\
\text { rate: } \mathrm{kg} / \mathrm{d}\end{array}$ \\
\hline 1991 & $1 \cdot 28$ & 0.97 \\
\hline 1992 & $1 \cdot 37$ & 0.99 \\
\hline 1993 & 1.43 & 1.02 \\
\hline 1994 & $1 \cdot 40$ & 1.01 \\
\hline 1995 & 1.27 & 1.01 \\
\hline 1996 & $1 \cdot 26$ & 0.97 \\
\hline 1997 & $1 \cdot 34$ & 1.04 \\
\hline 1998 & $1 \cdot 33$ & 1.04 \\
\hline 1999 & 1.40 & $1 \cdot 12$ \\
\hline 2000 & $1 \cdot 40$ & $1 \cdot 13$ \\
\hline 2001 & $1 \cdot 39$ & $1 \cdot 12$ \\
\hline 2002 & 1.40 & $1 \cdot 11$ \\
\hline 2003 & $1 \cdot 40$ & $1 \cdot 10$ \\
\hline 2004 & $1 \cdot 37$ & 1.03 \\
\hline 2005 & $1 \cdot 38$ & 1.00 \\
\hline 2006 & $1 \cdot 35$ & 0.97 \\
\hline 2007 & $1 \cdot 33$ & 0.92 \\
\hline 2008 & $1 \cdot 30$ & 0.87 \\
\hline 2009 & 1.29 & 0.86 \\
\hline 2010 & $1 \cdot 30$ & 0.87 \\
\hline 2011 & 1.27 & 0.84 \\
\hline 2012 & $1 \cdot 30$ & 0.88 \\
\hline 2013 & $1 \cdot 33$ & 0.88 \\
\hline
\end{tabular}

Table 6. MSW disposed and MSW recovered

\begin{tabular}{|c|c|c|}
\hline Year & MSW disposed: $1000 \mathrm{t}$ & MSW recovered: $1000 \mathrm{t}$ \\
\hline 1991 & 2700 & 1560 \\
\hline 1992 & 2890 & 1780 \\
\hline 1993 & 3090 & 1740 \\
\hline 1994 & 3080 & 1860 \\
\hline 1995 & 2850 & 1930 \\
\hline 1996 & 2970 & 1640 \\
\hline 1997 & 3170 & 1540 \\
\hline 1998 & 3190 & 1560 \\
\hline 1999 & 3380 & 1540 \\
\hline 2000 & 3420 & 1760 \\
\hline 2001 & 3390 & 1940 \\
\hline 2002 & 3440 & 1990 \\
\hline 2003 & 3450 & 1960 \\
\hline 2004 & 3400 & 2380 \\
\hline 2005 & 3420 & 2300 \\
\hline 2006 & 3390 & 2590 \\
\hline 2007 & 3350 & 2840 \\
\hline 2008 & 3300 & 2810 \\
\hline 2009 & 3270 & 3140 \\
\hline 2010 & 3330 & 3600 \\
\hline 2011 & 3280 & 3020 \\
\hline 2012 & 3396 & 2163 \\
\hline 2013 & 3485 & 2009 \\
\hline
\end{tabular}

Table 7 lists the quantities of waste disposed at landfills from the year 2005 to 2013 collected from the EPD of HK. These quantities have increased since 2007. The amount of waste 
Table 7. Quantities of waste disposal at landfills in 2005-2013

$\begin{array}{lrrrrrrrrr}\text { Quantity: } \mathbf{1 0 0 0 ~ t} & \mathbf{2 0 0 5} & \mathbf{2 0 0 6} & \mathbf{2 0 0 7} & \mathbf{2 0 0 8} & \mathbf{2 0 0 9} & \mathbf{2 0 1 0} & \mathbf{2 0 1 1} & \mathbf{2 0 1 2} & \mathbf{2 0 1 3} \\ \text { Domestic } & 2490 & 2420 & 2330 & 2230 & 2200 & 2240 & 2180 & 2301 & 2321 \\ \text { Commercial } & 690 & 750 & 800 & 830 & 850 & 860 & 861 & 827 & 879 \\ \text { Industrial } & 240 & 210 & 230 & 240 & 230 & 230 & 242 & 268 & 285 \\ \text { Construction } & 2390 & 1510 & 1150 & 1130 & 1140 & 1310 & 1216 & 1259 & 1311 \\ \text { Special } & 640 & 600 & 570 & 510 & 450 & 410 & 413 & 412 & 428 \\ \text { Total } & 6450 & 5490 & 5080 & 4940 & 4870 & 5050 & 4912 & 5067 & 5223\end{array}$

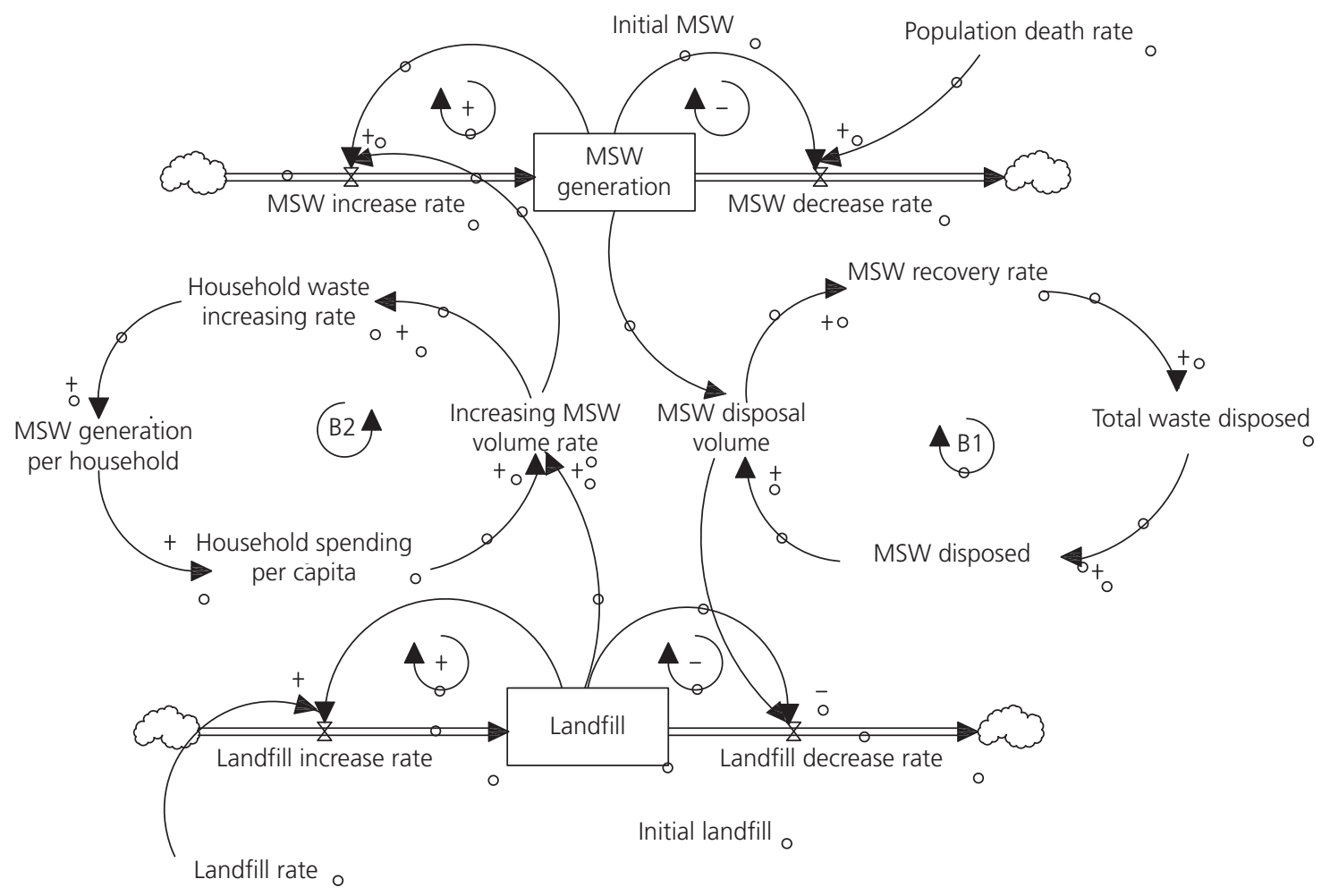

Figure 2. System-based MSW prediction and response model

disposed of declined in 2006 but increased at a rapid rate from 2007 onward and reached 5.223 Mt in 2013.

These data assisted with the determination of coefficients used in the SD modelling in Vensim 6.0 to project the future waste generation in HK. Disposal volumes were computed by MSW generation/recovery rate. The system-based prediction and response model in Figure 2 considers variables such as MSW volume rate, landfill rate for landfill capacity, MSW disposal volume, population and household spending.

Figure 3 is the tree diagram for the SD modelling, where Figure 3(a) shows the main variables used to compute the
MSW generation rate in HK; Figure 3(b) shows all consequences of landfills; and Figure 3(c) shows all consequences of MSW generation.

\subsection{Simulation results and finding}

Table 8 shows the sensitivity analysis on landfill recovery rates forecasting until 2025. The 'MSW landfill volume reduced' column shows the reduction in the landfill volume, which shows a positive sign that there is a decline in the landfill through the use of prevention methods by the government.

The simulation compares the forecasting of MSW generation and the total waste generation in HK until 2025, in which 


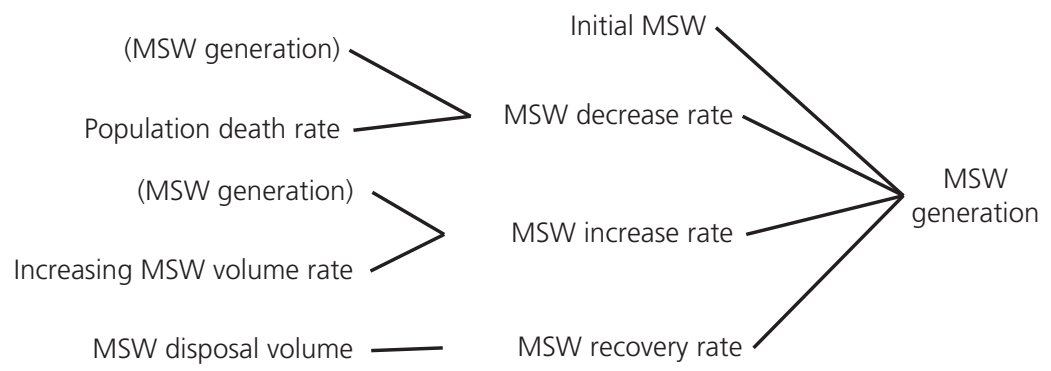

(a)

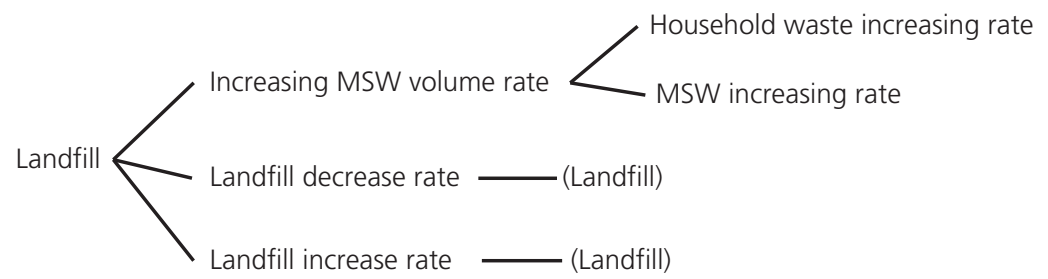

(b)

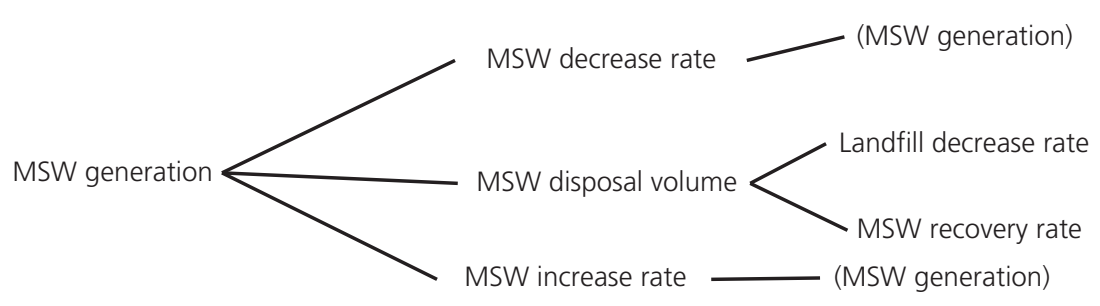

(c)

Figure 3. Tree diagrams for MSW in HK: (a) main variables used to compute the MSW generation rate in HK, (b) all consequences of landfills and (c) all consequences of MSW generation

Table 8. Simulation on landfill recovery rate

\begin{tabular}{|ccccc} 
Year & $\begin{array}{c}\text { Total waste generated } \\
\text { per day: } \mathbf{t}\end{array}$ & $\begin{array}{c}\text { Landfill prevention with } \\
\text { measures: } \mathbf{1 0 0 0} \mathbf{t}\end{array}$ & $\begin{array}{c}\text { Total waste landfill volume } \\
\text { reduced: } \mathbf{1 0 0 0} \mathbf{t}\end{array}$ \\
\hline 2013 & 14311 & 5151960 & 3245735 & 1906225 \\
2014 & 14798 & 5327280 & 3356186 & 1971094 \\
2015 & 15301 & 5508360 & 3470267 & 2038093 \\
2016 & 15821 & 5695560 & 3588203 & 2107357 \\
2017 & 16359 & 5889240 & 3710221 & 2179019 \\
2018 & 16915 & 6089400 & 3836322 & 2253078 \\
2019 & 17490 & 6296400 & 3966732 & 2329668 \\
2020 & 18085 & 6510600 & 4101678 & 2408922 \\
2021 & 18700 & 6732000 & 4241160 & 2490840 \\
2022 & 19335 & 6960600 & 4385178 & 2575422 \\
2023 & 19993 & 7197480 & 4534412 & 2663068 \\
2024 & 20673 & 7442280 & 4688636 & 2753644 \\
2025 & 20802 & 7488720 & 4792781 & 2770826 \\
\hline
\end{tabular}

MSW is constantly increasing but there is a slow decline in the growth of the MSW generation. Table 9 forecasts MSW generation and recycling until 2025 based on the simulation. The main reason for the higher increase from the year 2013 to 2022 is that the three remaining landfills will close between 2017 and 2019. After 2019, there will be no landfill available to dispose of MSW, which will lead to waste overflow in 2020. However, the HK government has identified this 
Table 9. Simulation on waste generation and recycled

\begin{tabular}{lccc}
$\begin{array}{l}\text { Time: } \\
\text { year }\end{array}$ & $\begin{array}{c}\text { Total waste } \\
\text { generation: Mt }\end{array}$ & $\begin{array}{c}\text { MSW } \\
\text { generation: } \mathbf{M t}\end{array}$ & $\begin{array}{c}\text { MSW } \\
\text { recycled: } \mathbf{M t}\end{array}$ \\
\hline 2013 & 5.152 & 3.437 & 1.272 \\
2014 & 5.327 & 3.554 & 1.315 \\
2015 & 5.508 & 3.675 & 1.360 \\
2016 & 5.696 & 3.800 & 1.406 \\
2017 & 5.889 & 3.929 & 1.454 \\
2018 & 6.089 & 4.062 & 1.503 \\
2019 & 6.296 & 4.200 & 1.554 \\
2020 & 6.511 & 4.343 & 1.737 \\
2021 & 6.732 & 4.461 & 1.784 \\
2022 & 6.914 & 4.581 & 1.832 \\
2023 & 7.100 & 4.705 & 1.882 \\
2024 & 7.292 & 4.832 & 1.933 \\
2025 & 7.489 & 4.962 & 1.985 \\
& & & \\
\hline
\end{tabular}

issue and is developing new landfills as a solution. The total waste generation in 2013 was $5 \cdot 152 \mathrm{Mt}$, and the MSW generation was $9547 \mathrm{t} / \mathrm{d}$ so that the annual MSW generation is $9547 \mathrm{t} \times 12 \times 30=3.437 \mathrm{Mt} /$ year. MSW in 2013 was $3.437 \mathrm{Mt} /$ year but increasing at a rapid pace due to the fast growth of population. Table 10 lists the historical data of MSW disposed at landfills from 2007 to 2013; this shows a fluctuation in the domestic solid waste from 2008, but it started to increase from 2011 to $2 \cdot 321 \mathrm{Mt}$ in 2013. The commercial solid waste disposal at landfills has also increased from 2007 to 2013. There is a general increase in the quantities of all types of solid waste disposed at the landfills from the year 2007 to 2013. The left graph in Figure 4 simulates the MSW recycled from the year 2013 to 2025 and showed that the recycling rate will increase in the near future. The middle graph in Figure 4 simulates the landfilled waste in HK. The right graph in Figure 4 shows the amount of waste prevented from going to landfill, which shows a similar, positive trend.

Figure 5 simulates the comparison among total waste generation, MSW generation and waste recycled until the year 2025. The amount of landfilled waste is below the level of MSW generation. The amount of landfilled waste is increasing over the coming decades. The high recycling rates may be due to the closure of landfills that are currently operating, forcing more waste to be effectively recycled with more advanced disposal techniques.

\subsection{Comparative discussions between HK, Singapore and Shanghai}

Semi-structured interviews were conducted with officers in the EPD of HK, Shanghai Environmental Protection Agency and the National Environmental Agency Singapore and related documentation was carefully studied. The fast economic and population growth in HK and Singapore have led to significant increases in MSW generation in both cities, leading to an increased environmental burden in relation to water, air and soil pollution, natural habitat degradation and various diseases. HK and Singapore are the most developed cities, major commercial hubs and financial centres in the Southeast Asia. Both are small but highly populated; Singapore is smaller than HK but has a greater population. Singapore has an annual MSW generation around $7 \mathrm{Mt}$ equivalent to $1 \cdot 3$ (t/capita)/year. The waste management policy in Singapore was developed by the National Environmental Agency Singapore, guided by three major policy platforms relating to waste minimisation, recycling at landfills and waste reduction through incineration. The total amount and proportion of MSW generation in HK and Singapore is very similar, but Singapore has a better MSW recovery and recycling rate than HK. The collection and disposal of industrial and commercial wastes in Singapore are paid for by commercial organisations instead of individuals, and this stimulates waste recycling. Currently, about $2000 \mathrm{t}$ of waste in Singapore is transported daily from the Tuas Marine station to the landfill. The landfill covers 350 ha, and it has been effectively managed to run for a long period. Singapore has a better landfill management and MSW processes than HK does.

Shanghai is the largest and most highly populated port city in the mainland China with an around 25 million population (An et al., 2014). Similar to HK and Singapore, Shanghai is also a global financial centre and a transport hub that has experienced rapid growth, urbanisation and industrialisation, all of which has generated significant increases in MSW (Gao, 2008). Shanghai has around 7.02 Mt waste per year of which $52 \%$ was disposed in landfills, $10 \%$ was composted, $16 \%$ was

Table 10. Quantities of solid waste disposed of at landfills in 2007-2013

\begin{tabular}{|c|c|c|c|c|c|c|c|}
\hline Quantity: Mt & 2007 & 2008 & 2009 & 2010 & 2011 & 2012 & 2013 \\
\hline Domestic & 2330 & 2230 & 2200 & 2240 & 2180 & 2301 & 2321 \\
\hline Commercial & 800 & 830 & 850 & 860 & 861 & 827 & 879 \\
\hline Industrial & 230 & 240 & 230 & 230 & 242 & 268 & 285 \\
\hline Construction & 1150 & 1130 & 1140 & 1310 & 1216 & 1259 & 1311 \\
\hline Special & 570 & 510 & 450 & 410 & 413 & 412 & 428 \\
\hline Total & 5080 & 4940 & 4870 & 5050 & 4912 & 5067 & 5223 \\
\hline
\end{tabular}



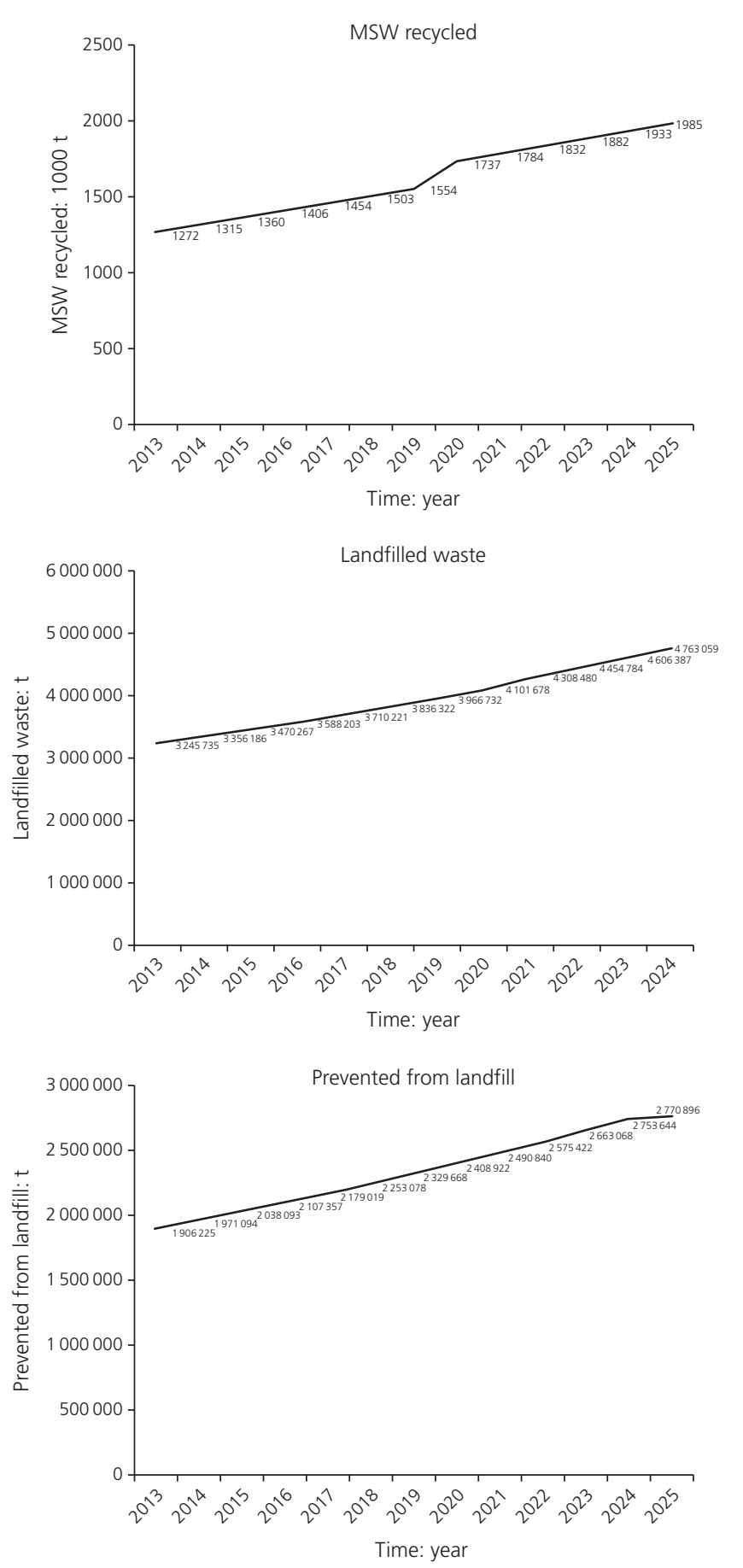

Figure 4. MSW recycled (top), landfilled waste (middle) and prevented from landfill (bottom)

incinerated and 19\% discarded at unsanitary landfills (Chung et al., 2010). The investment in waste processing and the construction of sewage treatment plants and sewer networks has been steadily improving in Shanghai (Chung et al., 2010).
Shanghai has about 30 small-to-medium-sized sewage treatment plants and three large sewage treatment plants ('Laogang', 'HK Bailong' and 'Chuk Yuen') handling up to $170 \mathrm{t}$ of waste daily (Zhang et al., 2012). Also, to improve the wastewater collection and treatment, $659 \mathrm{~km}$ of the pipeline has been newly laid. However, despite the good infrastructure, it seems some treatment plants are not connected to the sewerage system. While this kind of issue has certainly drawn great attention, it is subordinate to economic needs (Zhang et al., 2012). Shanghai has less MSW generation than HK over the last decades due to the more effective planning measures and government policies that have been enacted.

Among these three cities, HK has the highest MSW generation rates due to the less effective planning measures and government policies. Based on the interviews, some recommendations for HK were derived according to the experiences of Singapore and Shanghai in dealing with MSW generation. Singapore has implemented a national recycling programme, which is a voluntary programme for households as well as for trade premises. Under the national recycling programme, bags and bins are provided for waste storage, and these bags and bins are collected fortnightly; around $63 \%$ Singapore households participated in this programme. Apart from the MSW collection, Singapore has also implemented the waste minimisation hierarchy 'Towards Zero Landfill'. The main goal of the programme was to move the city towards zero landfill use by reducing waste generation. Payments received from commercial organisations, rather than individuals in Singapore, has played an important role in waste processing. Singapore also has the effective 'Recycling Corner Programme' that started in 2002 for schools to provide education and consultation to students about reducing, reusing and recycling waste; around $84 \%$ Singapore schools joined this programme, and it plays an important role in shaping the behaviours of future generations (Williams, 2014). HK could also implement the strategies learnt from Shanghai; for example, one useful strategy developed by the Environment Protection Agency Shanghai was to allocate special funds for waste management. Shanghai every year allots around US\$5 billion (3.05\% of the city GDP) for this purpose (Yang et al., 2014). The government of Shanghai charges US $\$ 0.44$ per month to each household for waste manage services.

\section{Conclusion}

Historical data regarding MSW generation in HK (including MSW volume rate, landfill rate for landfill capacity, MSW disposal volume, population and household spending) were used to determine coefficients in the SD modelling to project the future waste generation in HK. A system-based MSW prediction and response model was developed in this study using a seven-step SD model. The SD simulation forecasts the MSW 


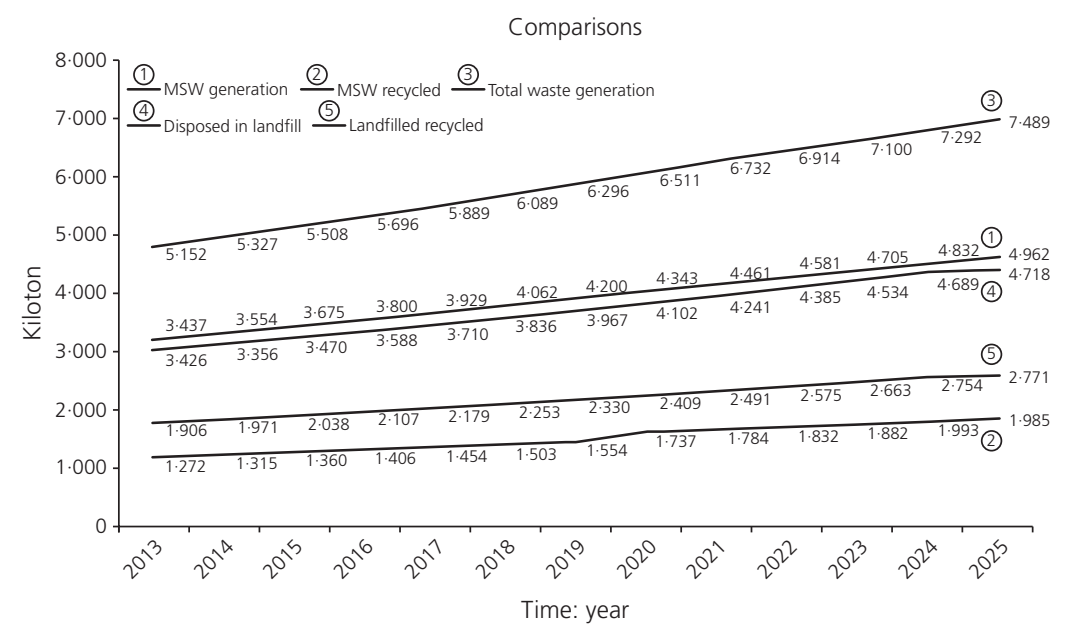

Figure 5. Comparison among waste generated, recycled, landfilled and landfilled recycled

generation and recycling in HK, which shows that in the near future the MSW will increase based on the current growth rates, and along with that the waste recycling will also improve. The strategies developed by the HK government regarding MSW disposal provide scope for further improvement because HK will experience more severe MSW conditions in the future as its landfills are expected to be closed earlier than planned. Compared with Singapore and Shanghai, HK has a higher MSW generation rate due to less effective planning measures and government policies. Recommendations for $\mathrm{HK}$ to support the management of MSW generation were derived according to the experiences of Singapore and Shanghai. HK could learn from Singapore and start programmes to provide education and consultation to school students on reducing, reusing and recycling of waste to shape and influence the behaviours of future generations. HK could also implement the strategies learnt from Shanghai to allocate special funds for waste management. Future studies are recommended to simulate the MSW generation and recycling in all these cities so that accurate comparison can be made that will allow the development of an effective solution for HK as well as the other two cities.

\section{REFERENCES}

Ali $\mathrm{N}$ and Sion $\mathrm{H}$ (2014) Solid waste management in Asian countries: a review of solid waste minimization $\left(3^{\prime} \mathrm{r}\right)$ towards low carbon. IOP Conference Series: Earth and Environmental Science. IOP Publishing, Bristol, UK, vol. 18, p. 012152.

An Y, Li G, Wu W et al. (2014) Generation, collection and transportation, disposal and recycling of kitchen waste: a case study in Shanghai. Waste Management and Research 32(3): 245-248.

Antmann E, Shi X, Celik N and Dai Y (2013) Continuous-discrete simulation based decision making framework for solid waste management and recycling programs. Computers and Industrial Engineering 65(3): 438-454.

Baawain M, Al-Mamun A, Omidvarborna $\mathrm{H}$ and Al-Amri W (2017) Ultimate composition analysis of municipal solid waste in Muscat. Journal of Cleaner Production 148: 355-362, https://doi.org/ 10.1016/j.jclepro.2017.02.013.

Bernstad A (2014) Household food waste separation behavior and the importance of convenience. Waste Management 34(7): 1317-1323.

Cai P, Wang K, Kong S and Li J (2014) Application of video capture theory in municipal solid waste classification. Advanced Materials Research 908: 408-411, https://doi.org/10.4028/www.scientific.net/ AMR.908.408.

Chan W (2001) Environmental accounting of municipal solid waste originating from rooms and restaurants in the HK hotel industry. Journal of Hospitality and Tourism Research 25(4): 371-385.

Chen H, Zhang C and Wang T (2013) Adsorption of methylene blue onto char from pyrolysis of municipal solid waste. Applied Mechanics and Materials 345: 163-166, https://doi.org/10.4028/ www.scientific.net/AMM.345.163.

Chowdhury M (2009) Searching quality data for municipal solid waste planning. Waste Management 29(8): 2240-2247.

Chung S (2010) Projecting municipal solid waste: the case of HK SAR. Resources, Conservation and Recycling 54(11): $759-768$

Chung S, Lau K and Zhang C (2010) Measuring bulky waste arisings in HK. Waste Management 30(5): 737-743.

Gao M (2008) College of Information Engineering, Shanghai Maritime University, Shanghai 200135, China. Journal of Computer Applications 28(6): 1411-1413.

Gidarakos E (2015) War and environmental impacts. Waste Management 35(1): 1-2.

Han H, Li Y and Qiao J (2014) A fuzzy neural network approach for online fault detection in waste water treatment process. Computers and Electrical Engineering 40(7): 2216-2226.

Hong J, Li X and Zhaojie C (2010) Life cycle assessment of four municipal solid waste management scenarios in China. Waste Management 30(11): 2362-2369. 
Hong J, Chen Y, Wang M et al. (2017) Intensification of municipal solid waste disposal in China. Renewable and Sustainable Energy Reviews 69: 168-176, https://doi.org/10.1016/j.rser.2016.11.185.

Inghels D and Dullaert W (2010) An analysis of household waste management policy using system dynamics modelling. Waste Management and Research 29(4): 351-370.

Jaillon L, Poon C and Chiang Y (2009) Quantifying the waste reduction potential of using prefabrication in building construction in HK. Waste Management 29(1): 309-320.

Kollikkathara N, Feng $\mathrm{H}$ and Stern E (2009) A purview of waste management evolution: special emphasis on USA. Waste Management 29(2): 974-985.

Lam W and Chan K (2014) How authoritarianism intensifies punctuated equilibrium: the dynamics of policy attention in HK. Governance 28(4): 212-223.

Lavee D and Khatib M (2010) Benchmarking in municipal solid waste recycling. Waste Management 30(11): 2204-2208.

Lee CKM, Yeung CL, Xiong ZR and Chung SH (2016) A mathematical model for municipal solid waste management: a case study in Hong Kong. Waste Management 58: 430-441, https://doi.org/ 10.1016/j.wasman.2016.06.017.

Ling B (2015) Introduction to the HK Basic Law. The China Quarterly 221: 258-259, https://doi.org/10.1017/S0305741015000144.

Liu Z and Li H (2015) Extreme learning machine based spatiotemporal modelling of lithium-ion battery thermal dynamics. Journal of Power Sources 277: 228-238, https://doi.org/10.1016/j.jpowsour. 2014.12.013.

Liyanage B, Gurusinghe R, Herat S and Tateda M (2015) Case study: finding better solutions for municipal solid waste management in a semi local authority in Sri Lanka. Open Journal of Civil Engineering 5(1): 63-73.

Lu W and Yuan H (2013) Investigating waste reduction potential in the upstream processes of offshore prefabrication construction.
Renewable and Sustainable Energy Reviews 28: 804-811, https:// doi.org/10.1016/j.rser.2013.08.048.

Machowski J, Bialek J and Bumby J (2008) Power System Dynamics. Wiley, Chichester, UK.

Prades M, Gallardo A and Ibàñez M (2014) Factors determining waste generation in Spanish towns and cities. Environmental Monitoring and Assessment 187(1): 2-5.

Wang J, Zhao H, Zhong $X$ et al. (2011) Investigation of mercury levels in soil around a municipal solid waste incinerator in Shenzhen, China. Environmental Earth Sciences 64(4): 1001-1010.

Wei Y, Li J, Shi D et al. (2017) Environmental challenges impeding the composting of biodegradable municipal solid waste: a critical review. Resources, Conservation and Recycling 122: 51-65, https:// doi.org/10.1016/j.resconrec.2017.01.024.

Williams I (2014) The importance of education to waste (resource) management. Waste Management 34(11): 1909-1910.

Yang J, Fujiwara T, Matsuoka Y and Wang W (2014) A systematic approach to projecting industrial solid waste generation by industrial sector in Shanghai. Journal of Material Cycles and Waste Management 18(1): 1-12.

Yau Y (2010) Domestic waste recycling, collective action and economic incentive: the case in HK. Waste Management 30(12): 2440-2447.

Yu A, Poon C, Wong A, Yip R and Jaillon L (2013) Impact of construction waste disposal charging scheme on work practices at construction sites in HK. Waste Management 33(1): 138-146.

Zhang W, Che Y, Yang K, Ren X and Tai J (2012) Public opinion about the source separation of municipal solid waste in Shanghai, China. Waste Management and Research 30(12): 1261-1271.

Zhou H, Meng A, Long Y, Li Q and Zhang Y (2015) A review of dioxin-related substances during municipal solid waste incineration. Waste Management 36: 106-118, https://doi.org/ 10.1016/j.wasman.2014.11.011.

\section{How can you contribute?}

To discuss this paper, please email up to 500 words to the editor at journals@ice.org.uk. Your contribution will be forwarded to the author(s) for a reply and, if considered appropriate by the editorial board, it will be published as discussion in a future issue of the journal.

Proceedings journals rely entirely on contributions from the civil engineering profession (and allied disciplines).

Information about how to submit your paper online is available at www.icevirtuallibrary.com/page/authors, where you will also find detailed author guidelines. 